\title{
ISOLATION, IDENTIFICATION AND MOLECULAR CHARACTERIZATION OF SERRATIA MARCESCENS STRAIN NMRL65 AN OPPORTUNISTIC HUMAN PATHOGEN FROM THE SPOILED COCONUT
}

\author{
Rajamani Mohanram $^{1^{*}}$, Murlidhar J Mendki ${ }^{1}$, Susan Titus ${ }^{1}$ \\ ${ }^{1}$ Department of Marine Biotechnology, Naval Materials Research Laboratory, \\ Defence Research and Development Organisation, Shill-Badlapur Road, \\ Additional Ambernath-East, Maharashtra, India
}

\begin{abstract}
Microbes are the common cause of food spoilage and are widely distributed in the environment. Fruits and vegetables provide ideal nutrient conditions for the survival and growth of many types of bacteria. Bacteria responsible for food spoilage produce extracellular hydrolytic enzymes which bring about the deterioration of the food products. Coconut flesh is highly nutritious and rich in saturated fat, sugar and potassium that have wide range of health benefits. Fresh coconut flesh is often spoiled by red pigment producing bacterium Serratia. The present study was therefore undertaken and a red pigment producing opportunistic human pathogen Serratia marcescens strain NMRL 65 from spoiled coconut was isolated, identified and characterized for specific genes. Also its ability to produce multiple hydrolytic extracellular enzymes like chitinase, lipase and protease was investigated and reported.
\end{abstract}

\section{Keywords}

Food spoilage bacteria, Serratia marcescens, opportunistic human pathogen, lipase, protease, coconut,

\section{Introduction}

Many countries around the world are facing food insecurity due to increasing global human population. The second goal of United Nations Sustainable Development is to endhunger in all its forms by 2030 and to achieve food security. Large proportions of food products are spoiled during the food supply chain by food spoilage microorganisms. One third of the food products produced for human population are either spoiled or wasted according to Food and Agriculture Organization of the United Nations 2011 report.Food spoilage is broadly defined as a change in the quality of food items that makes it undesirable for human consumption, due to spoilage indicators such as bad odour, texture and appearance [1]. The cause of food spoilage is a complex process broadly grouped as microbiological, chemical and physical [2]. Microorganisms responsible for food spoilage are bacteria, fungi and yeast. Microbes are able to survive in different environmental conditions like high salt, sugar, acidic and alkaline. Fruits with high water and sugar content are easily spoiled by microbes. Fresh coconut flesh is easily spoiled by bacteria, fungi and yeast due to its sugar, fat and water content.
The Serratia genus are Gram negative, facultative anaerobic bacteria, which grow in a broad range of temperatures and substrates, including plant surfaces, soil, water, and food products such as fruit juices, coconut and fish. Serratia marcescens and $S$. rubidaea is commonly found as a contaminant in wet coconut as a pink or red colour colonies. The red pigment produced by $S$. marcescens is prodigiosin. Prodigiosin is produced in the later stages of bacterial growth, although it doesn't have any physiological role in producing organisms, it's reported to have antibacterial, antifungal, antiprotozoal and antitumor properties [3].

Serratia marcescens produces wide range of extracellular hydrolytic enzymes such as chitinase, protease and lipase, due to this it is able to degrade and spoil edible food items rich in protein and fat. The presence of $S$. marcescens in an edible food items like coconut should be considered as a cause of concern because it's classified as an opportunistic human pathogen. About 2\% of nosocomial infections of the bloodstream, lower respiratory tract, urinary tract, surgical wounds and skin and soft tissues of adult persons are caused by Serratia[4]. 
Quorum sensing allows bacterial populations to communicate and coordinate group behaviour and commonly is used by pathogens in disease and infection processes. Quorum sensing systems controls a diverse range of cell density dependent factors such as antibiotic, biosurfactant production, extracellular polysaccharide, biofilm differentiation, cell division and pathogenecity. Serratia utilizes two types of quorum sensing signalling molecules: $\mathrm{N}$-acyl homoserine lactones (AHLs, AI-1) and AI-2 type signalling molecules. The two key enzymes in AI-2 signalling molecules in Serratia is $\mathrm{S}-\mathrm{ribos} y \mathrm{~h}$ omocystein ase $(L u x S)$ and Sadenosylhomocysteine nucleosidase $(P f s)$ are responsible for biosynthesis of signalling molecules, which contribute to virulence factors of the human opportunistic pathogen $S$. marcescens[5].

To detect and identify the presence of $S$. marcescens-an opportunistic pathogen in edible food products like coconut, using reliable, rapid and internationally accepted test methods is of great importance. In this study a red pigment producing bacterium was isolated from spoiled coconut and identified using $S$. marcescens species specific polymerase chain reaction as $S$. marcescens strain NMRL65. The genes coding for serrawettin biosurfactant production, chitinase, serrapeptidase, S-ribosylhomocysteinase (LuxS) and Sadenosylhomocysteine nucleosidase $(P f \mathrm{~s})$ were alsodetected in S. marcesccens strain NMRL65 by polymerase chain reaction.

\section{MATERIALSAND METHODS}

All the microbiological media used were procured from $\mathrm{Hi}$ Media Laboratory Pvt., Ltd. (Mumbai, India). Molecular biology reagents were procured from Thermo Fisher Scientific (USA). Water used throughout was of Milli-Q grade.

\subsection{Sample Collection}

Spoiled wet coconut with pinkish red colour discoloration was collected from D2/6, Residential Quarters of Naval Materials Research Laboratory, Ambernath.

\subsection{Isolation of bacteria from pinkish red discoloured spoiled coconut}

The pinkish red discoloured spoiled coconut was swabbed using sterile wooden cotton swab (Hi-Media Labs Pvt., Ltd. Mumbai) and inoculated in $50 \mathrm{ml}$ of sterile Nutrient Broth in $250 \mathrm{ml}$ conical flask and incubated in an rotary shaker (Orbitek Shaker, Scigenics Pvt. Ltd., Chennai, India) at $28^{\circ} \mathrm{C}$ for 48 hour. After 48 hours $10 \mu 1$ of reddish nutrient broth was inoculated in prepared sterile Nutrient Agar (NA) petri-plates and quadrilateral streaking was done and incubated in microbiological incubator at $28^{\circ} \mathrm{C}$ for 48 hours to isolate food spoilage bacteria. The red pigmented colony was selected and detailed morphological, biochemical and molecular biology characterization was done. The red pigmented bacterial isolate was labelled as strain NMRL65 and stored in glycerol stock at $-80^{\circ} \mathrm{C}$ for further characterization [6].

23 Identification of red pigment producing bacterium $S$. marscecensstrain NMRL65 from spoiled coconut using S.marscecens species specific polymerase chain reaction Total DNA extraction of bacterial strain NMRL65 was performed using DNeasy ultraclean microbial kit (Qiagen, Germany). The strain NMRL65 was further identified till the species level by using primers specially designed for the identification of $S$. marcescens based on the 16S rRNA sequence alignment of different environmental isolates [7].The nucleotides sequence of $S$. marcescens species specific forward primer are Smar16SV89-108 -5'GGGAGCTTGCTCACTGGGTG-3'and reverse primer Smar 16SWR 499-471-5'- GCGAGTAACGTCA GTTGATGAGCGTATTA-3'. The PCR amplification was performed in the total volume of $25 \mu \mathrm{l}$ in $200 \mu$ l capacity thin wall PCR tube consisting of $7.5 \mu 1$ of PCR grade water, $12.5 \mu \mathrm{l}$ of 2X PCR master mix (Thermo Scientific), $1 \mu \mathrm{l}$ (10 picomoles) of each primer, and $3 \mu$ l of template DNA (50 picomoles). Amplification was performed in a thermal cycler Mastercycler epgradient PCR machine (Eppendorf, Hamburg, Germany). The temperature profile for PCR was kept, $95^{\circ} \mathrm{C}$ for $3 \mathrm{~min}, 94^{\circ} \mathrm{C}$ for $0.5 \mathrm{~min}, 69^{\circ} \mathrm{C}$ for $1 \mathrm{~min}, 72^{\circ} \mathrm{C}$ for $0.45 \mathrm{~min}, 35$ cycles and final extension at $72^{\circ} \mathrm{C}$ for $10 \mathrm{~min}$. The PCR product was then electrophoresed in $1.2 \%$ agarose and documented using G:Box gel document system (Syngene, USA).

\section{Morphological and Biochemical identification of $S$. marcescens strain NMRL65}

The morphological characterizations of the strain NMRL65 was carried out by Gram Staining and hanging drop method for motility. To determine the lipase activity the strain NMRL 65 was streaked on lipase medium (peptone $10 \mathrm{~g}$, sodium chloride $5 \mathrm{~g}$, calcium chloride $0.1 \mathrm{~g}$, Tween $8010 \mathrm{ml}$, agar $20 \mathrm{~g}$ dissolved in $1000 \mathrm{ml}$ of distilled water). After 3 days of incubation at $28^{\circ} \mathrm{C}$, the lipase activity was indicated by the powdery deposit zone surrounding the colonies. Protease enzyme was determined using skimmed milk agar (pancreatic digest of casein $5 \mathrm{~g}$, yeast extract $2.5 \mathrm{~g}$, glucose $1 \mathrm{~g}, 7 \%$ skimmed milk solution $100 \mathrm{ml}$, agar $15 \mathrm{~g}$ dissolved in $1000 \mathrm{ml}$ distilled water). After 2 days of incubation at $30^{\circ} \mathrm{C}$, a clear zone around the cells indicated positive proteolytic activity [8].

Phosphate solubilizing enzyme was determined by the development of a clear zone in Pikovskaya's agar medium (yeast extract $0.5 \mathrm{~g}$, dextrose $10 \mathrm{~g}$, calcium phosphate $5 \mathrm{~g}$, ammonium sulphate $0.5 \mathrm{~g}$, potassium chloride $0.2 \mathrm{~g}$, magnesium chloride $0.1 \mathrm{~g}$, manganous sulphate $0.0001 \mathrm{~g}$, ferrous sulphate $0.0001 \mathrm{~g}$, agar $15 \mathrm{~g}$ dissolved in $1000 \mathrm{ml}$ distilled water) after 2-5 days incubation of assay plates at $30^{\circ} \mathrm{C}[9]$. 


\section{Detection of $\operatorname{chiA}$ gene coding for chitinase A enzyme in S. marcescens strain NMRL 65 by PCR}

The ChiA gene coding for chintinase A enzyme in strain NMRL 65 was detected using reported $c h i A$ specific primers : 5 '-GATAT CGACTGGGAGTTCCC-3' ( forward; corresponding to nucleotide positions $931-950$ of $\mathrm{S}$. marcescens X03657) and 5'-CATAGA AGTCGTA GGTCATC-3' (reverse: positions 1180-1161) flanked a 225 bp fragment[10]. The PCR amplification was performed in the total volume of $25 \mu \mathrm{l}$ in $200 \mu \mathrm{l}$ capacity thin wall PCR tube consisting of $7.5 \mu \mathrm{l}$ of PCR grade water, $12.5 \mu \mathrm{l}$ of $2 \mathrm{X}$ PCR master mix (Thermo Scientific), $1 \mu \mathrm{l}$ (10 picomoles) of each primer, and $3 \mu \mathrm{l}$ of template DNA (50 picomoles). Amplification was performed in a thermal cycler Mastercycler epgradient PCR machine (Eppendorf, Hamburg, Germany). The temperature profile for PCR was kept, $95^{\circ} \mathrm{C}$ for $3 \mathrm{~min}, 95^{\circ} \mathrm{C}$ for $0.25 \mathrm{~min}, 58^{\circ} \mathrm{C}$ for $1 \mathrm{~min}, 72^{\circ}$ $\mathrm{C}$ for $0.25 \mathrm{~min}, 35$ cycles and final extension at $72^{\circ} \mathrm{C}$ for 10 min. PCR products were visualized by agarose gel electrophoresis and documented using G:Box gel document system (Syngene, USA).

\subsection{Detection of Serrapeptidase gene in S. marcescens strain NMRL 65 by PCR}

The serrapeptidase gene was amplified in strain NMRL 65 using specific forward Ser pep (L): 5'-GGAAGCTTCATATG CAATCTACTAAAAAGGCAAT-3' and reverse [Ser pep (R): 5'- GCGAAGCTTAC ACGATAAAGTAGT GGCGACGT$3^{\prime}[11]$. The PCR amplification was performed in the total volume of $25 \mu \mathrm{l}$ in $200 \mu \mathrm{l}$ capacity thin wall PCR tube consisting of $7.5 \mu \mathrm{l}$ of PCR grade water, $12.5 \mu \mathrm{l}$ of $2 \mathrm{X}$ PCR master mix ( Thermo Scientific), $1 \mu \mathrm{l}$ (10 picomoles) of each primer, and $3 \mu \mathrm{l}$ of template DNA (50 picomoles). Amplification was performed in a thermal cycler Mastercycler epgradient PCR machine (Eppendorf, Hamburg, Germany). The temperature profile for PCR was kept, $95^{\circ} \mathrm{C}$ for $3 \mathrm{~min}, 95^{\circ} \mathrm{C}$ for $1.5 \mathrm{~min}, 60^{\circ} \mathrm{C}$ for $1 \mathrm{~min}, 72^{\circ} \mathrm{C}$ for $1.5 \mathrm{~min}, 35$ cycles and final extension at $72^{\circ} \mathrm{C}$ for $10 \mathrm{~min}$. PCR products were visualized by agarose gel electrophoresis and documented using G:Box gel document system (Syngene, USA).

27 Detection of $p f s$ and luxS genes involved in AI-2 Dependent quorum sensing in $S$. marcescens strain NMRL 65 byPCR

The S-ribosylhomocysteinase $(\operatorname{Lux} S)$ and $\mathrm{S}$ adenosylhomocysteine nucleosidase $(P f s)$ enzymes are responsible for synthesis of signalling molecules, which contribute to virulence factors of the human opportunistic pathogen Serratia and other genes of unknown function via quorum sensing. The luxS and pfs gene was detected in strain NMRL 65 using primers specific for Serratialux $S$ and $p f s$ gene. The primers used for luxS are FluxS1- 5'G CTGGAACACCTGTTCGC-3' and RluxS2-5' ATGTAGAAACCGGTGCGG-3', the primers used for pfs are
Fpfs1-5' CCGGCATCGGCAAAGTCT-3' and Rpfs2 -5'ATCTGGCCCGGCTCGTAGCC-3'[12]. The PCR amplification was performed in the total volume of $25 \mu \mathrm{l}$ in $200 \mu \mathrm{l}$ capacity thin wall PCR tube consisting of $7.5 \mu \mathrm{l}$ of PCR grade water, $12.5 \mu \mathrm{l}$ of $2 \mathrm{X}$ PCR master mix (Thermo Scientific), $1 \mu \mathrm{l}$ (10 picomoles) of each primer, and $3 \mu \mathrm{l}$ of template DNA (50 picomoles). Amplification was performed in a thermal cycler Mastercycler epgradient PCR machine (Eppendorf, Hamburg, Germany). The temperature profile for PCR was kept, $95^{\circ} \mathrm{C}$ for $3 \mathrm{~min}, 95^{\circ} \mathrm{C}$ for $45 \mathrm{~s}, 55^{\circ} \mathrm{C}$ for $0.5 \mathrm{~min}, 72^{\circ} \mathrm{C}$ for $15 \mathrm{~s}, 30$ cycles and final extension at $72^{\circ} \mathrm{C}$ for $10 \mathrm{~min}$. PCR products were visualized by agarose gel electrophoresis and documented using G:Box gel document system (Syngene, USA).

28 Detection of putative SwrWgene required for biosurfactant serrawettin W1 production in $S$. marcescens strain NMRL65

The SwrW gne which encodes putative serrawettin W1 synthase was detected in strain NMRL65 using primers SW2F3 5'-GCG ACA AAA GCA ATG ACA AA-3') and SW2-R3 5'-GTC GGC GTA TTG TTC CAA CT-3'[13]. The PCR amplification was performed in the total volume of $25 \mu \mathrm{l}$ in $200 \mu \mathrm{l}$ capacity thin wall PCR tube consisting of $7.5 \mu \mathrm{l}$ of PCR grade water, $12.5 \mu \mathrm{l}$ of $2 \mathrm{X}$ PCR master mix (Thermo Scientific), $1 \mu \mathrm{l}$ (10 picomoles) of each primer, and $3 \mu \mathrm{l}$ of template DNA (50 picomoles). Amplification was performed in a thermal cycler Mastercycler epgradient PCR machine (Eppendorf, Hamburg,Germany). The temperature profile for PCR initial denaturation at $95^{\circ} \mathrm{C}$ for $3 \mathrm{~min}, 95^{\circ} \mathrm{C}$ for $30 \mathrm{~s}$ and extension $72^{\circ} \mathrm{C}$ for $50 \mathrm{sec}, 30$ cycles of denaturation at $94^{\circ} \mathrm{C}, 0.45 \mathrm{mins}$, annealing $55^{\circ} \mathrm{C}, 0.45 \mathrm{~min}$, and extension at $72^{\circ} \mathrm{C}, 3 \mathrm{~min} ; 1$ cycle of final extension at $72^{\circ} \mathrm{C}, 10 \mathrm{~min}$. Polymerase chain reaction (PCR) products were stored at $4^{\circ} \mathrm{C}$. PCR products were visualized by agarose gel electrophoresis and documented using G:Box gel document system (Syngene, USA).

\section{RESULTSAND DISCUSSION}

3.1 Morphological and Biochemical characterization of $S$. marcescens strainNMRL65

The $S$. marcescens strain NMRL 65 isolated from pinkish reddish discoloured spoiled coconut (Figure 1a) was characterized by Gram staining as Gram negative rods, and hanging drop method revealed motile rods. The strain NMRL65 produced non diffusible red pigment prodigiosin in nutrient agar after 48 hours of incubation at $28^{\circ} \mathrm{C}$ as shown in Figure 1b. The strain NMRL 65 hydrolyzed casein in skimmed milk agar producing clear zone around colonies after 48 hours which indicated the protease enzyme production as shown in Figure 2a. This enzyme plays a role in spoilage of protein rich food items like milk [14].

Lipase assay using Tween 80 as substrate revealed the hydrolysis which produced powdery deposit around the strain 
NMRL 65 colonies as shown in Figure 2b. Due to the production of lipase enzyme $S$. marcescens strain NMRL 65 was able to spoil food products which are rich in fats like coconut and milk [15].

The strain NMRL 65 was able to solubilise inorganic calcium
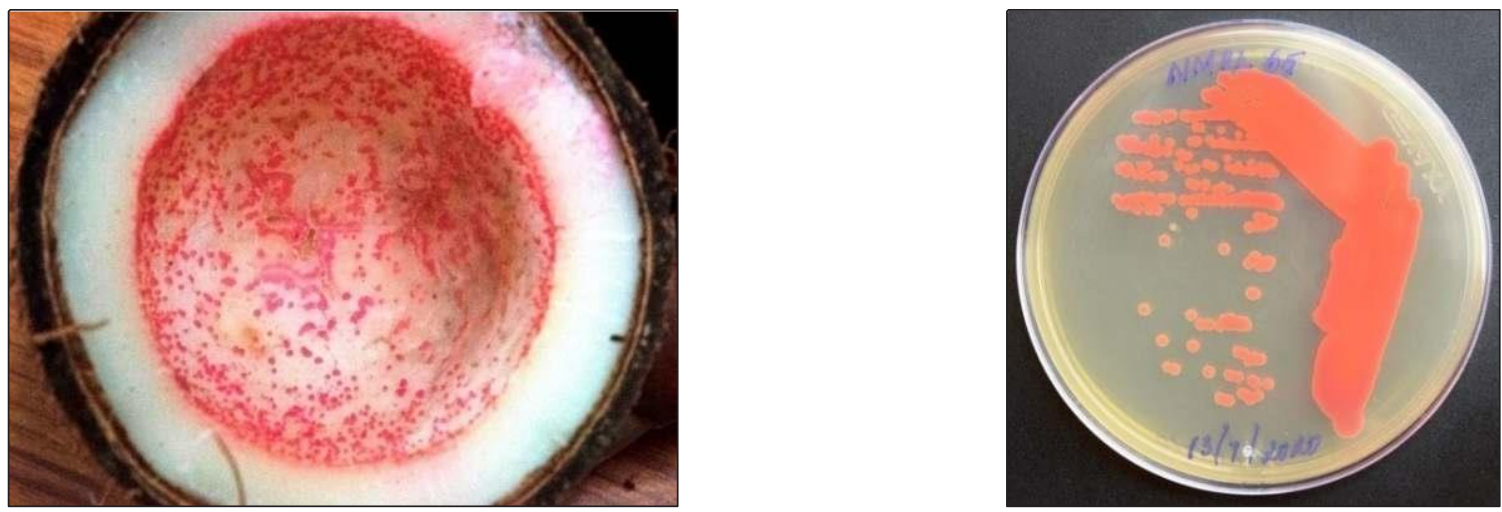

Figure 1: (a) A pinkish red discoloured spoiled fresh wet coconut (b) Isolated a red pigmented producing $S$. marcescens strain NMRL 65 in nutrient agar incubated at $28^{\circ} \mathrm{C}$ for 48 hours.
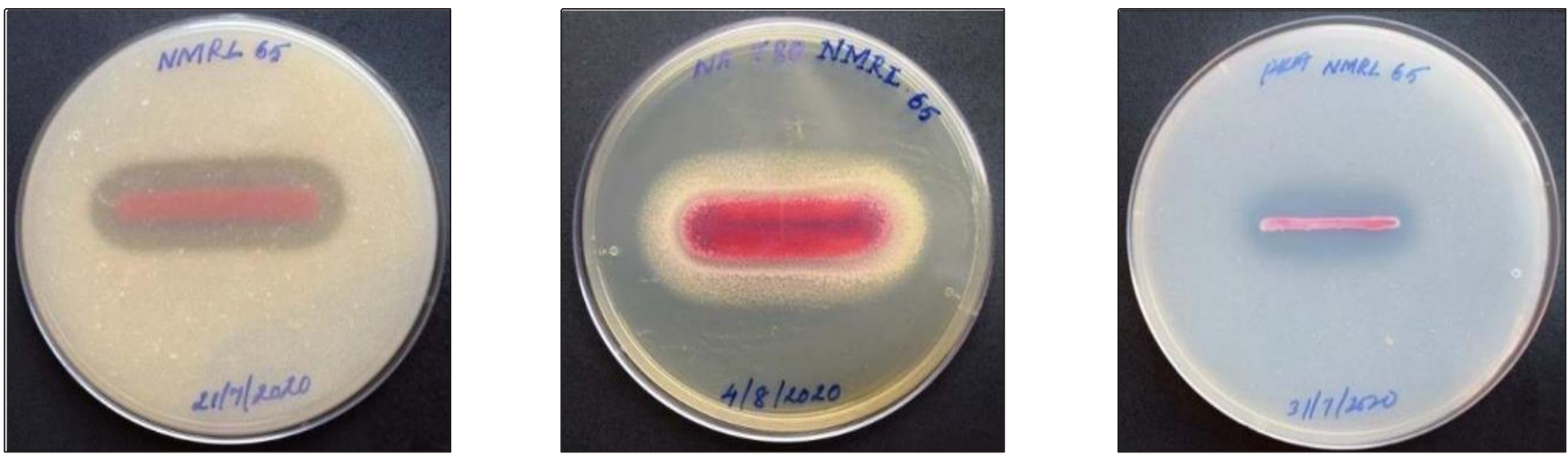

Figure 2: (a) Protease plate assay for S. marcescens strain NMRL65 in skimmed milk agar. (b) Lipase plate assay for S. marcescens strain NMRL65 in nutrient agar with $0.1 \%$ calcium chloride and $1 \%$ Tween 80 . (c) Phosphate solubilising plate assay in Pikovskaya's agar.

\subsection{Molecular Identification of $S$. marcescens strain} NMRL65 by $S$. marcescens species specific PCR

The amplification of PCR product of $417 \mathrm{bp}$ (Figure 3 Lane 5) from the genomic DNA of strain NMRL25 using $S$. marcescens species specific primer confirmed the strain NMRL65 as $S$. marcescens. A prodigiosin producing $S$. marcescens isolated from soil was identified by species level by using $S$. marcescens species specific primer [19]. phosphate by producing phosphate solubilising enzyme as shown in Figure 2c. Many researchers have reported phosphate solubilising capabilities of $S$. marcescensisolated from agricultural soils [16-18]. 


\subsection{Molecular characterization of $S$. marcescens strain NMRL65}

The amplification of 225 bp PCR products in S. marcescens strain NMRL 65 (Figure 3. Lane 4) using reported chiA gene primer designed based on $S$. marcescens sequence confirmed the presence of chitinase A enzyme producing capabilities of the strain NMRL65. Many researchers have reported the presence of chiA gene in $S$. marcescens and its role in spoilage of chitin rich sea foods like shrimps [20,21].

The amplification of 1500 bp PCR products in S. marcescens strain NMRL65 (Figure 3. Lane 7) using primer designed based on $S$. marcescens sequence confirmed the presence of Serrapeptidase enzyme capacity of this stain. Serrapeptidase is also known as miracle enzyme which can be used to dissolve blood clots and shrink varicose veins. Many researchers worldwide reported the production of serrapeptidase from $S$. marcescens [22-24].

The amplification of 900bp PCR (Figure 3, Lane 6) products in $S$. marcescens strain NMRL 65 using primer specific for serrawettin W1 synthase confirmed the biosurfactant producing property of this strain. Due to the biosurfactant producing ability $S$. marcesens is able to colonize wide range of substrates in the environment [25].

The amplification of 102bp and 193bp PCR products (Figure 3, Lane 2\&3) in $S$. marcescens strain NMRl 65 using primer specific for S-ribosylhomocysteinase (LuxS) Sadenosylhomocysteine nucleosidase $(P f s)$ sequence of Serratia confirmed the presence of this two key enzymes in AI-2 dependent quorum sensing signal molecules in this strain. The quorum sensing based PCR test method can be used to detect $S$. marcescens from various environments like spoiled food items and animal host. Zhu et al., 2008 [12] reported detection of luxS and pfs in 27 different Serratia strains.

\section{Conclusion}

S. marcescens is widely distributed in air and cause deterioration of food products. Wet coconut rich in sugar, fat and water content is easily colonized and spoiled by this food spoilage bacterium. The $S$. marcescens species specific PCR method can be employed for rapid detection and identification of $S$. marcesens in spoiled food items.

\section{Acknowledgement:}

The authors would like to express their gratitude to the Director, NMRL, Ambernath for his constant support and encouragement.

\section{Conflict of Interest}

The authors declare that there is no conflict of interest.

\section{REFERENCES}

1. Odeyemi O. A., Alegbeleye OO, Strateva M, Strateva D.Understanding spoilage microbial community and spoilage mechanisms in foods of animal origin.Comprehensive Reviews in Food Science and Food Safety.2020;19:311-331.

2. Petruzzi L, Corbo M R, Sinigaglia, M, Bevilacqua,A. Microbial spoilage of foods: Fundamentals. In: A. Bevilacqua, M. R. Corbo, \& M. Sinigaglia (Eds.), The Microbiological Quality of Food. Duxford, UK: Woodhead Publishing. 2017; Chapter 1:1-21.

3. Siva R, Subha K, Bhakta D, Ghosh A R, Babu S. Characterization and enhanced production of prodigiosin from the spoiled coconut. Applied Biochemistry and Biotechnology. 2012; 166:187-196.

4. Yokota M, Okazawa A, Tanaka T.Serratia marcescens as an opportunistic human pathogen. Nippon Saikingaku Zasshi. 2002; 56:527-535.

5. Schauder S, Shokat K, Surette MG, Bassler BL. The LuxS family of bacterial autoinducers: biosynthesis of a novel quorum sensing signal molecule. Molecular Microbiology. 2001; 41:463-476.

6. Mohanram R, Jagtap C, Kumar P. Isolation, screening and characterization of surface active agent producing oil degrading marine bacteria of Mumbai harbour. Marine Pollution Bulletin. 2016; 105:131-138.

7. Wilson VL, Tatford BC, Yin X, Rajki SC, Walsh MM, LaRock P. Species specific detection of hydrocarbon utilizing bacteria. Journal of Microbiological Methods. 1999; 39: 59-78.

8. Smibert RM, Kreig NR. Phenotypic characterization. In: Methods for General and Molecular Biology ed. Gerhardt, PRG., Murray, E., Wood, W.A. and Kreig, N.R. Washington, DC: American Society for Microbiology. 607-654.

9. Pikovskaya RI. Mobilization of phosphorous in soil in connection with vital activity of some microbial species. Mikrobiologiya. 1948;17:363-370.

10. Ramiah N, Hill R T, Chun J, Ravel J, Matte MH, Straube W L, Colwell RR.Use of a chiA probe for detection of chitinase genes in bacteria from the Chesapeake Bay. FEMS Microbiology Ecology.2000;34:63-71.

11. Kaviyarasi NS, Sarkar S, Suryanarayana VVS.Characterization of gene encoding serrapeptidase from Serratia marcescens (SRM) MTCC 8708 a plant isolate. International Journal of Current Microbiology and Applied Sciences. 2015;4(8):206-214.

12. Zhu H, Sun S. Dang H. PCR Detection of Serratia spp. Using Primers Targeting $p f s$ and luxS Genes Involved in AI- 2 - Dependent Quorum Sensing. Current Microbiology. 2008; 57: 326-330. 
13. Apao MMN, Teves GF, Ma RSBM. Sequence analysis of putative swrW gene required for surfactant serrawettin W1 production from Serratia marcescens. African Journal of Biotechnology. 2012; 11(57):12040-12044.

14. Machado SG, Heyndrickx M, Block JD, Devreese B, Vandenberghe I,Vanetti MCD, Coillie EV. Identification and characterization of a heat resistant protease from Serratia liquefaciens isolated from a Brazalian cold raw milk. International Journal of Food Microbiology. 2016;222:65-71.

15. Wessels D, Jooste PJ, Mostert JF.Psychrotrophic, proteolytic and lipolytic properties of Enterobacteriaceae isolated from milk and dairy products. International Journal of Food Microbiology. 1989; 9: 79-83.

16. Rodriquez R, Fraga R, Gonsalez T, Bashan Y. Genetics of phosphate solubilisation and its potential applications for improving plant growth promoting bacteria. Plant and Soil. 2006; 287: 15-21.

17. Farhat MB, Farhat A, Bejar W, Kammoun R, Bouchaala K, Fourati H, Antoun H, Bejar S, Chouayekh H. Characterization of the mineral phosphate solubilising activity of Serratia marcescens CTM 50650 isolated from the phosphate mine of Gafsa.Archives of Microbiology.2009; 191: 815-824.

18. Hameeda B, Harini G, Rupela OP, Wani SP, Reddy G. Growth promotion of maize by phosphate solubilising bacteria from compost and macrofauna. Microbiological Research. 2008; 163: 234-242.
19. Giri AV, Anandkumar N, Muthukumaran G, Pennathur G. A novel medium for the enhanced cell growth and production of prodigiosin from Serratia marcescens isolated from soil. BMC Microbiology. 2004;4(11) https://doi.org/10.1186/1471-2180-4-11.

20. Fadhil L, Kadim A, Mahdi A. Production of chintase by Serratia marcescens from soil and its antifungal activity. Journal of Natural Sciences Research. 2014; 4 (8) : 80-86.

21. Nawani N, Kapadnis BP. One step purification of chitinase from Serratia marcescens NK1, a soil isolate. Journal of Applied Microbiology.2001;90:80-83.

22. Yamasaki H, Tsuji H, Siki K. Anti-inflamatory action of a protease TSP produced by a Serratia. Folia Pharmocology Japan. 1967;8: 302-314.

23. Mohankumar A, Raj HKR. Production and characterization of serratiopeptidase enzyme from Serratia marcescens. International Journal of Biology. 2011;3: 39-51.

24. Tao K, Yu X, Liu Y, Shi G, Liu S, Hou T. Cloning, expression and purification of insecticidal protein Pr596 from locust pathogen Serratia marcescens HR 3. Current Microbiology. 2007; 55(3): 228-233.

25. Chan XY, Chang CY, Hong KW, Tee KK, Yin WF, Chan KG. Insights of biosurfactant producing Serratia marcescens strain W2.3 isolated from tapia fish a draft genome analysis. Gut Pathogens. 2013 ; 5:29.10.1186/1757-4749-5-29. 